\title{
William Bartram: A Maker and Painter of America's Image in its Enlightenment
}

By Matthew Jagas

One of the more interesting, yet lesser-known figures of the eighteenth-century American Enlightenment is the naturalist William Bartram. Despite his relative obscurity as an important enlightened American, being overshadowed by more prominent figures such as Benjamin Franklin and Thomas Jefferson, Bartram is revered, according to historian Judith Magee, as "the most influential single figure in natural history in pre-revolutionary America." ${ }^{1}$ His significant botanical observations and discoveries contributed greatly to the universal body of natural history. Yet, a far more significant aspect of Bartram is the role his science played in the development of America in the Age of Enlightenment. Bartram's work helped to place American science in the world of European science, showing to Europe that American nature was by no means inferior to its own. As well, Bartram's primary work, Travels through North \& South Carolina, etc, along with the scientific works of men such as Thomas Jefferson, helped to show America's ability to act independently of Britain. ${ }^{2}$ His accounting, classifying and describing of American nature, along with his abundant artwork, also had a significant role in resolving the issue of European supremacy in natural history. They showed to the world an image of America that was at once wild and new yet capable and civilized. An analysis of William Bartram, specifically of his Travels and its influence, will show the difficulties facing American science in the Age of Enlightenment and the quest of the new nation to develop its image.

Before examining the significance of Bartram's work in America, it will first be useful for further analysis to provide some important biographical information. William Bartram was born in Kingsessing, Philadelphia in 1739 to Ann and John Bartram. John was also a highlyrespected naturalist in America as well as an influential figure in the American Enlightenment, playing an important role in the natural scientific exchange between the Old World and the New. $\mathrm{He}$ is also most famously known for having helped found the American Philosophical Society with Benjamin Franklin in $1743 .^{3}$ At a young age, William would often accompany his father on his botanical expeditions where he developed his passion for investigating nature and especially for illustrating his observations. He received an enlightened and classical education at the Philadelphia Academy, where he was introduced to the works of such prominent Enlightenment figures as Locke, Pope, Newton, Bacon, and Hutcheson. ${ }^{4}$ 
After having failed in his first career attempt as a merchant, and then again in his second as a rice planter, Bartram managed to gain the patronage of a prominent English doctor. Dr. John Fothergill, a botanist friend of his father, agreed to fund him in his surveying expedition of the American South. Bartram set out on this expedition in 1773, travelling for four years through Georgia, Florida then North and South Carolina, in which places he documented his findings and described his travels. After having returned to Philadelphia in 1777, he wrote his famous Travels, for which he gained much of his fame. When Travels circulated throughout Europe, for example, as Magee notes, he was considered there to be "one of the greatest American naturalists during his lifetime." Later, Bartram settled in his family home where he tended the famous Bartram Garden to his death in 1823.

Bartram's Travels was first published in 1791, but it is not his only work. In 1774, he wrote a "Report to Dr. John Fothergill" in which he records the observations of his journey up to that time. ${ }^{6}$ Nevertheless, Travels is his principal public work and the work for which he was most known throughout the scientific community. It is also the work through which historians may observe the impact of Bartram on the American Enlightenment and American science. However, while his report to Fothergill parallels events in Travels, as historian Thomas Slaughter notes in his book, The Natures of John and William Bartram, it "offers a strikingly different account of William's journey." In general, his report aims for more "scientific credibility" than does his Travels. ${ }^{8}$ For example, in Travels, there is a notable lack of dates and many of the dates it does contain are inaccurate, whereas the dating in the report is much more accurate. While it is indeed curious to see this difference between his public and private works, and while the relatively unscientific nature of Travels may have, as Slaughter argues, been calculated for "literary effect," the purpose and significance of Travels seems to be in much more than the simple coming of age story, which Slaughter suggests. ${ }^{9}$ Neither is its significance mainly due to its influence on the Romantic writers of the early nineteenth century, as other historians have suggested; it is rather in its purpose of responding to a particular problem in American natural science. ${ }^{10}$

Bartram came upon the world of Enlightenment science as American science continued to experience a major issue. As Magee explains, since "contact with Europe was the key to all scientific development," America struggled to act independently of Europe, just as it had in its pre-revolutionary politics. ${ }^{11}$ One event in the Bartrams' early travels to the South presents an 
exemplary case of this issue. In 1765, they made an important discovery of a new species of plant, which they named the Franklin tree (Franklinia alatamaha) after their friend "the illustrious Dr. Benjamin Franklin." 12 In 1783 after his own travels, William wrote to the celebrated Swedish botanist Carl Linnaeus in order to present Franklinia as a new discovery and establish it as a new genus. However, Linnaeus having passed away before his authority might settle the matter, a dispute arose between American and European botanists about the plant's proper genus. European authorities eventually rejected the claim of it being new, leading one current American authority on Franklinia, Joel Fry, to remark that it was likely done with the intention of enforcing "European supremacy in botanical nomenclature." ${ }^{13}$ Having so recently asserted its political independence from Britain and having shown itself to the Old World as a new nation, America yet struggled to show itself to be a capable nation in its science. This struggle, Bartram, together with men like Thomas Jefferson, would have a significant role in resolving.

This European supremacy in natural history was due mainly to the belief among Europeans that in general, American species were inferior to their own. Many Europeans scientists promulgated this theory, most notably the renowned French naturalist the Comte de Buffon, in his Histoire Naturelle. Buffon argued, according to historian Keith Thomson that the species of the New World "were always smaller and weaker" than their European counterparts, European livestock exported to America often became "stunted" and in general they had fewer variety of species. ${ }^{14}$ Such degeneracy, Buffon continued, had to do mainly with climate and could not fail to effectively degenerate the human population as well, as he argued to have been the case with Native Americans. ${ }^{15}$ The major problem with such accusations was not simply the issue of their authenticity, but rather as Thomson notes, that anything which "lessened public opinion of America... had political significance." ${ }^{16}$ The deplorable conception of America's nature in the mind of Europeans, in short, damaged its overall image and added to its overall inferiority as a nation.

Clearly, the issue facing American natural history reached far deeper than a simple scientific dispute: it was about forming its own image as well as asserting its equality and independence among all nations, as it had done in the Declaration of Independence. Thomas Jefferson clearly understood this and thus, in his Notes on the State of Virginia, he spends pages in describing the natural environment of Virginia, listing its species in the manner of a naturalist 
and devoting almost an entire chapter to refuting Buffon and the European conception of America's nature. ${ }^{17}$ This has led one historian, Susan Manning, to see Jefferson's work not simply as a geographical description of Virginia, but as "an intellectual and patriotic discovery of the emergent nation." 18 It is similarly as a response to the issue of this misunderstood European conception that Bartram, like Jefferson, holds special scientific significance. According to Magee, Bartram would “[corroborate] Jefferson's arguments," helping to display a proper image of America and "demonstrate that American flora and fauna were comparable to those of Europe." 19

The most evident way in which Bartram begins the repairing of America's scientific image is through his classification of the various species he comes across in his Travels. Before doing this, however, Bartram seems to introduce the problem of European supremacy in his introduction. In the vegetable kingdom, he notes: "it is difficult to pronounce which division of the earth, within the polar circles, produces the greatest variety [of species]. ${ }^{, 20}$ He then proceeds, as though he was about to refute the Europeans' claims, to list the various species which inhabit different parts of the earth: those in the "tropical division" and those in the "temperate zone."21 Then coming to the animal, he names and extols the varieties of species found among this kingdom. ${ }^{22}$ In this way, Bartram's work, as much as Jefferson's "attempts to counteract prevailing myths about America with "facts,"” according to Manning, also refutes the "myth" of European supremacy. ${ }^{23}$

Bartram further places American species into equality with those of Europe by his employment of Linnaeus' standardized and universal names of species in his many descriptions; the same way that Jefferson had done in his Notes. While his documentation of species are usually scattered throughout the narrative of his journey, beginning his descriptions as he comes upon new places, many times he breaks the narrative to fully document and classify a species. ${ }^{24}$ On one most exemplary occasion, Bartram fully breaks from the book's narrative to describe and classify several species of snakes, but continues his classification into a long list of all of the species he encounters on his journey. ${ }^{25}$ This particular list is remarkably comparable to those in Linnaeus' Systema Naturae as well as those in Jefferson's Notes. ${ }^{26}$ The use of the universal names of species would have then allowed European naturalists to recognize the species he encounters and scientifically construct the world around him. One early British review of 
Bartram's Travels, published in the Monthly Review, for example, states: "the naturalist will be gratified by lists of such peculiar plants and trees as Mr. Bartram observed."27

As much as his extensive descriptions aid naturalists, they also serve to help the reader accurately construct an image of the American landscape. Reading through his Travels, one is able to follow Bartram through field, marsh, forest, and river and see that America is not entirely different from Europe. In a particularly descriptive passage, Bartram constructs for his readers the great Alachua Savanna, which presents "unlimited, varied, and truly astonishing native wild scenes." 28 Also, his many excursions in nature, such as his long and exciting encounter with crocodiles on the St. John's River in East Florida, show the wildness of an America yet to be tamed, while his civilized encounters with Native Indians shows an America able to be tamed. ${ }^{29}$ That these two types of encounters were subjects of the mentioned review article, and that, as Magee observes, Travels received wide acclaim in Europe, shows that Europeans were indeed attentive to Bartram's illustration of America. ${ }^{30}$ His descriptions together with his classifications of nature, helped to thus repair the scientific image of America, showing that it was not only equal, but indeed, newer and more robust than Europe.

Bartram's writings certainly began to construct the image of America in the minds of Europeans. However, according to Magee, "the scientific listings, descriptions, and observations... were viewed as secondary" to his work's other elements. ${ }^{31}$ Specifically, as an early twentieth-century historian Nathan Fagin explains, Bartram ultimately "saw nature with the eyes of a painter." 32 Therefore, just as his descriptions of nature helped to equalize American species with those of Europe, so too did his illustrations. While in the catalogue of his various illustrations provided by Magee in her book, one finds many intensely accurate drawings of perfectly ordinary species, such as a mallard or a warmouth fish, one also finds some very peculiar drawings. One, for example, depicts a standing cardinal beside an Atlantic croaker, seeming to float in the air. ${ }^{33}$ The purpose, as historian Michael Gaudio suggests, of this juxtaposition is to show that the bird and the fish have "a similar elliptical form," and to emphasize the particular as well as the universal. ${ }^{34}$ Yet, such emphasis is typical of Bartram's art and serves to encourage the viewer not only to regard the differences of nature but also the similarities. In doing so, Bartram tacitly suggests to his readers that though species differ from place to place, they are nonetheless comparable and worthy of praise; that their differences are 
not a question of superiority, but all equally manifest the "wisdom and beneficence of the Supreme Creator."35

The full significance of Bartram's artwork, however, to American science and thus the full significance of his whole work in general can be more fully realized if one considers the importance of visual representation in early Enlightenment science. In the Age of Enlightenment, according to historian Martin Rudwick, visuals, stuffed specimen, samples and especially "making pictures of the natural world," were "essential part[s] of the practice of natural history." ${ }^{36}$ Observing and collecting in the field was considered secondary to "the concentration of species in one place," which allowed species to be "compared with others from elsewhere, and so be identified and classified." ${ }^{37}$ Consequently, while his classification of species in his descriptions of nature first gave readers a partial view of America, it was mainly through his artwork that Bartram allowed Europeans to observe more fully American nature for themselves and ultimately contributed to the painting of America's scientific portrait.

After his travels into the American South, Bartram planted many of the species he gathered on his journey in his family garden that soon became a famous site for naturalists to travel to. Although his work was over, his influence did not diminish. As Magee explains, years after his Travels, "naturalists, travelers, and politicians, including Jefferson and Washington," all made their way to the Bartram home. ${ }^{38}$ Jefferson, for a time, even lived across the river from the house. All sought Bartram for his "encouragement, friendship and above all generosity in sharing his knowledge of natural history with them" and eventually Bartram would become a key figure in shaping latter important naturalists such as Alexander Wilson, who would be called, as Magee notes, "the father of American ornithology." 39 By his interaction with such men as came to visit him, he shared through his knowledge of nature gathered during his travels, his "vision for the future of the nation" and encouraged them to continue to form America's image. ${ }^{40}$

Although he is not well known among the prominent men of eighteenth-century America, William Bartram, his life and his works, was certainly no less significant. At a time when American science struggled to assert itself in the increasingly scientific world of the Enlightenment, being belittled in the European scientific community by its supposed "degenerate" and "lesser" natural world, Bartram's work, primarily his Travels, served to help dispel such myths about the new nation. Along with Thomas Jefferson's Notes on the State of Virginia, Travels, through its many descriptions and classifications of species, effectively 
presented American species as being equivalent to those of Europe. As well, accompanied by his abundant illustrations of American wildlife, Bartram's work helped to form the image of America as at once a new and wild nation but one that was yet familiar, by no means inferior, and one that was furthermore, as it now was in its politics, independent.

\section{NOTES}

${ }^{1}$ Judith Magee, The Art and Science of William Bartram (Pennsylvania: Pennsylvania State University Press, 2007), 8 .

${ }^{2}$ William Bartram, Travels Through North \& South Carolina, Georgia, East \& West Florida, the Cherokee Country, the Extensive Territories of the Muscogulges, or Creek Confederacy, and the Country of the Chactaws; Containing An Account of the Soil and Natural Productions of Those Regions, Together with Observations on the Manners of the Indians (Philadelphia: James \& Johnson, 1791), transcribed by Apex Data Services Inc. 2001. Electronic Edition.

${ }^{3}$ Magee, The Art and Science of William Bartram, 27.

${ }^{4}$ Ibid., 37.

${ }^{5}$ Ibid., 133.

${ }^{6}$ William Bartram, Francis Harper, "Travels in Georgia, and Florida, 1773-74. A Report to Dr. John Fothergill.” In Transactions of the American Philosophical Society 33 no. 2. (1943): 121-242.

7 Thomas Slaughter, The Natures of John and William Bartram (New York: Alfred A. Knopf, Inc., 1996), 178.

${ }^{8}$ Ibid., 190.

${ }^{9}$ Ibid.

${ }^{10}$ Magee explains the influence of Travels on the Romantics. See Magee, The Art and Science of William Bartram, 131-140. Historian Hugh Moore argues for Bartram's significance as a pre-Romantic in his article. Hugh Moore, "The Southern Landscape of William Bartram: A Terrible Beauty" in Essays in Arts and Sciences 10, no. 1 (1981): 41-50. Published electronically in Nineteenth-Century Literature Criticism 145, (2005) by Literature Resource Center.

${ }^{11}$ Magee, The Art and Science of William Bartram, 6.

12 Ibid., 64, Bartram, Travels, 467.

13 Joel Fry, as cited in Magee, The Art and Science of William Bartram, 67.

${ }^{14}$ Thomas Jefferson, Notes on the State of Virginia, in The Portable Thomas Jefferson, ed. Merrill D. Peterson (New York: Penguin Books, 1977), 78.

${ }^{15}$ Keith Thomson, "Jefferson Buffon and the Moose" in American Scientist 96, no. 3 (2008): 200.

${ }^{16}$ Ibid.

17 Jefferson, Notes on the State of Virginia, 68-111.

${ }^{18}$ Susan Manning, "Naming of Parts; or, the Comforts of Classification: Thomas Jefferson's Construction of America as Fact and Myth," Journal of American Studies 30, no. 3 (1996): 348.

${ }^{19}$ Magee, The Art and Science of William Bartram, 123.

${ }^{20}$ Bartram, Travels, xiv.

${ }^{21}$ Ibid., xiv-xxi.

${ }^{22}$ Ibid., xxi-xxii.

${ }^{23}$ Manning, "Naming of Parts; or, the Comforts of Classification," 358.

${ }^{24}$ Bartram, Travels, 170-180.

${ }^{25}$ Ibid., 264-302.

${ }^{26}$ See Carl von Linné, A General System of Nature: etc. (London: Lackington, Allen and Co., 1802) and Jefferson, Notes on the State of Virginia, 68-72.

27 “Art II: Travels, etc. Philadelphia: James \& Johnson, 1791” in The Monthly Review 10, no. 2 (1793): 13-22, 131.

${ }^{28}$ Bartram, Travels, 187-190.

${ }^{29}$ Ibid., 117-130, 20-23.

30 “Art II: Travels, etc. Philadelphia: James \& Johnson, 1791.” 13-22, 131-138 and Magee, The Art and Science of William Bartram, 131.
} 
${ }^{31}$ Ibid., 123.

${ }^{32}$ N. Bryllion Fagin, William Bartram: Interpreter of the American Landscape (Baltimore: John Hopkins Press, 1933), 107.

${ }^{33}$ Magee does not provide the titles of the art pieces, only their descriptions. I will, therefore, only provide their depictions and page numbers: "Mallard," "Warmouth," "Cardinal and Atlantic Croaker," as depicted in Magee, The Art and Science of William Bartram, 89, 148, 92.

${ }^{34}$ Michael Gaudio, "Swallowing the Evidence: William Bartram and the Limits of Enlightenment" in Winterthur Portfolio 36, no. 1 (2001), 4.

${ }_{36}^{35}$ Bartram, Travels, xxiii.

${ }^{36}$ Martin Rudwick, "Picturing Nature in the Age of Enlightenment" in Proceedings of the American Philosophical Society 149, no. 3 (2005): 303.

${ }^{37}$ Rudwick, "Picturing Nature in the Age of Enlightenment," 283.

${ }^{38}$ Magee, The Art and Science of William Bartram, 158.

${ }^{39}$ Ibid., 158-159.

${ }^{40}$ Ibid., 123. 